\title{
GEORGIA: TECHNICAL ASSISTANCE REPORT-LIQUIDITY MANAGEMENT OPERATIONS
}




\section{INTERNATIONAL MONETARY FUND}

IMF Country Report No. 17/107

\section{GEORGIA}

\section{TECHNICAL ASSISTANCE REPORT-LIQUIDITY MANAGEMENT OPERATIONS}

This Technical Assistance report on Georgia was prepared by a staff team of the International Monetary Fund. It is based on the information available at the time it was completed in December 2016.

\footnotetext{
Copies of this report are available to the public from International Monetary Fund $\bullet$ Publication Services PO Box 92780 - Washington, D.C. 20090

Telephone: (202) 623-7430 • Fax: (202) 623-7201

E-mail: publications@imf.org Web: http://www.imf.org Price: $\$ 18.00$ per printed copy
}

\section{International Monetary Fund Washington, D.C.}




\title{
INTERNATIONAL MONETARY FUND
}

\author{
Monetary and Capital Markets Department
}

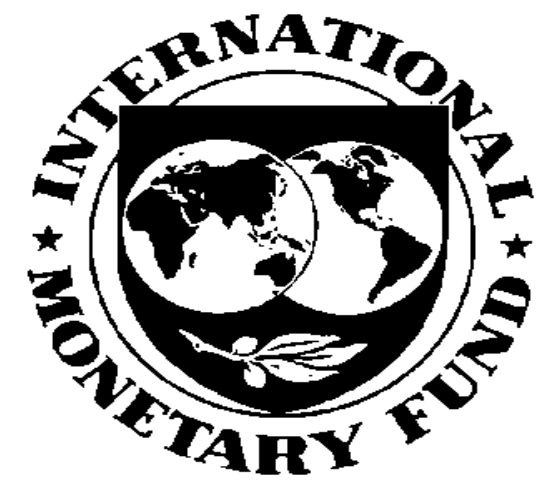

\section{GEORGIA}

\section{LiQUidity MANAGEMENT OPERATIONS}

\author{
Diarmuid Murphy (Mission Chief)
}

December 2016 
The contents of this report constitute technical advice provided by the staff of the International Monetary Fund (IMF) to the authorities of Georgia (the "TA recipient") in response to their request for technical assistance. This report (in whole or in part) or summaries thereof may be disclosed by the IMF to IMF Executive Directors and members of their staff, as well as to other agencies or instrumentalities of the TA recipient, and upon their request, to World Bank staff and other technical assistance providers and donors with legitimate interest, unless the TA recipient specifically objects to such disclosure (see Operational Guidelines for the Dissemination of Technical Assistance Informationhttps://www.imf.org/external/np/pp/eng/2013/061013.pdf).

Disclosure of this report (in whole or in part) or summaries thereof to parties outside the IMF other than agencies or instrumentalities of the TA recipient, World Bank staff, other technical assistance providers and donors with legitimate interest shall require the explicit consent of the TA recipient and the IMF's Monetary and Capital Markets Department. 


\section{Contents}

Glossary

Preface. $\underline{5}$

Executive Summary $\underline{6}$

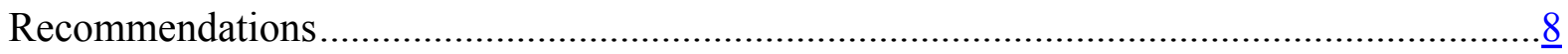

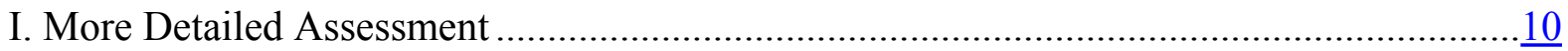

A. National Bank of Georgia’s Monetary Policy Framework …..................................10

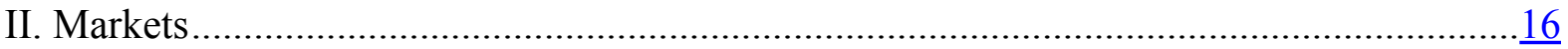

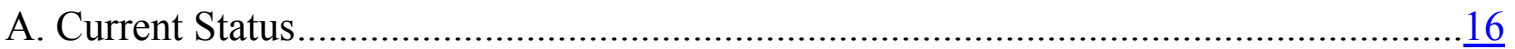

B. Assessment and Recommendations .............................................................

III. National Bank of Georgia's Liquidity Monitoring ............................................. 18

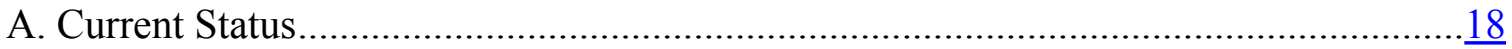

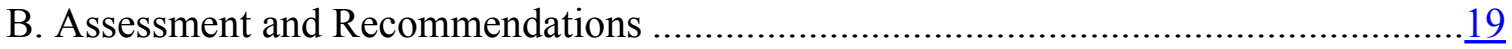

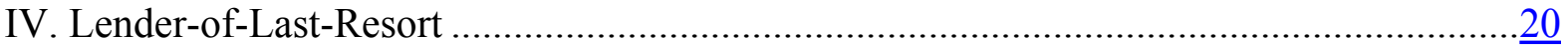

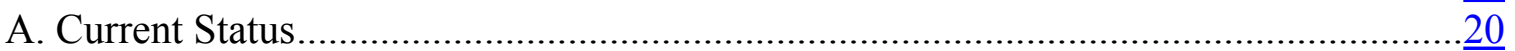

B. Assessment and Recommendations ............................................................... 


\section{GLOSSARY}

$\begin{array}{ll}\text { BIS } & \text { Bank for International Settlements } \\ \text { BOE } & \text { Bank of England } \\ \text { BP } & \text { Basis Point } \\ \text { CCA } & \text { Caucasus and Central Asia } \\ \text { CD } & \text { Certificate of Deposit } \\ \text { CLF } & \text { Committed Liquidity Facility } \\ \text { ECB } & \text { European Central Bank } \\ \text { ELA } & \text { Emergency Liquidity Assistance } \\ \text { FSD } & \text { Financial Stability Department } \\ \text { FX } & \text { Foreign Exchange } \\ \text { GEL } & \text { Georgian lari } \\ \text { GMRA } & \text { Global Master Repurchase Agreement } \\ \text { HQLA } & \text { High Quality Liquid Assets } \\ \text { IFI } & \text { International Financial Institution } \\ \text { IMF } & \text { International Monetary Fund } \\ \text { IT } & \text { Inflation Targeting } \\ \text { LCR } & \text { Liquidity Coverage Ratio } \\ \text { LD } & \text { Legal Department } \\ \text { LOLR } & \text { Lender-of-Last-Resort } \\ \text { ILTR } & \text { Indexed Long-term Repo } \\ \text { MCM } & \text { Monetary and Capital Markets Department of the IMF } \\ \text { MoF } & \text { Ministry of Finance } \\ \text { MoU } & \text { Memorandum of Understanding } \\ \text { NBG } & \text { National Bank of Georgia } \\ \text { TA } & \text { Technical Assistance }\end{array}$




\section{PREFACE}

At the request of Mr. Archil Mestvirishvili, the Deputy Governor of the National Bank of Georgia (NBG), a mission from the Monetary and Capital Markets Department (MCM) of the International Monetary Fund (IMF) visited Tbilisi from October 27-30, 2016. The purpose of the mission was to gain an understanding of current NBG liquidity management arrangements, interbank market activity, along with the management of liquidity risks within the Georgian banking system, and establish a roadmap for future technical assistance (TA) work in this area.

The mission team wishes to express its appreciation to the management and staff of the NBG for their excellent cooperation and generous hospitality.

This note provides a summary of the key inputs provided by the IMF team comprising Diarmuid Murphy (Mission Chief), building on discussions with the NBG staff and management, and meetings with four commercial banks (two large banks and two mediumsized banks active in the interbank lending and foreign exchange (FX) markets). It was agreed that the main areas of work, and a possible sequencing of this work would be discussed further in Washington D.C. during the 2016 Annual Meetings (during the Annual Meetings it was agreed that further engagement between MCM and the NBG would take place in early 2017). This note contains the mission's main findings and recommendations, however, accompanying appendices prepared by the IMF team have been removed. 


\section{EXECUTIVE SUMMARY}

The National Bank of Georgia (NBG) has embarked on an ambitious project to strengthen monetary policy implementation so that its actions in normal times are seen by the market as being both credible and predictable. As part of this work, the NBG is putting in place arrangements to provide comfort to the market that it stands ready to respond to systemic events, while being conscious of the need to structure its operations in a way so that the system's ability to self-ensure is not undermined. It is clear that a great deal of thought and preparation has gone into this work, and also in explaining to the market the reasons for its monetary policy actions.

Overall, the NBG strategic framework is guided by the need to strike a balance. This is between the benefits of greater exchange rate flexibility for the current inflation targeting (IT) monetary regime and the need to take on board relevant macrofinancial features of the Georgian economy, something which is a difficult task. Nonetheless, it is clear from discussions with market participants that there is a high level of credibility enjoyed by the NBG and this has certainly played an important role in anchoring inflation expectations. However, a key vulnerability remains, namely the high level of dollarization in the system (credit and deposit dollarization levels within the Georgian economy stand at just over 60 percent), but through a joint NBG-Government working group, the authorities are actively trying to pursue a de-dollarization policy.

It was agreed that the main areas of work, and a possible sequencing of this work would be discussed further in Washington D.C. during the 2016 Annual Meetings. At this stage, there are three broad headings under which future TA could continue:

\section{Financial deepening}

A national effort is required in the area of financial development and responsibility should not fall on the shoulders of the NBG alone. A well-articulated national financial development plan - involving the NBG, the Ministry of Finance (MoF), and other regulatory bodies - would help ensure that individual actions are aligned with the broader development goals, and provide a roadmap for the process of financial deepening in a safe and effective way.

\section{Liquidity risk monitoring and management}

The NBG is actively implementing its new liquidity coverage ratio (LCR) as a means of better capturing the liquidity risks of banks. An intrinsic part of this framework will be the level of run-off ratios, which as currently calibrated provide more positive treatment to FX deposits rather than those of local currency (Georgian lari). It could be useful to revisit the calibration of these ratios and the overall structure of the LCR to ensure that liquidity risks are being accuracy measured, term funding is being encouraged, and that its structure is not inconsistent with the NBG's de-dollarization policy. 


\section{Liquidity forecasting is a key part of a central bank's sound liquidity management} framework. In particular, the capability of the government to prepare accurate cash-flow projections and share them with the central bank on a timely basis is vital for overall liquidity projections, since variations in the net position of the government often account for the most significant changes in liquidity supply. To assist the NBG with its monetary policy implementation, it could be useful to formalize Georgian treasury forecasts and understand further the NBG's short-term liquidity forecasting framework. Related to this, further engagement with MCM could be helpful before FX swaps and interest rate swaps, currently being considered by the NBG, are introduced as part of the NBG's standard framework.

NBG credibility around its monetary policy operations could be further supported through the creation of an operational guideline. This publically available document could pull together all elements of the NBG's operational framework, including its standard operations, and main elements of its systemic and idiosyncratic responses. This could also be supported by the development of an internal operational manual detailing elements such as roles, responsibilities, and contingency arrangements, etc.

\section{Lender-of-last-resort}

The NBG has the ability to provide lender-of-last-resort (LOLR) liquidity, but there is a benefit in making this framework more robust. Elements include eliminating unsecured lending, having explicit solvency, and viability requirements; but the NBG could also look to establish internal guidelines covering elements such as: internal governance; collateral and counterparty policy; risk control measures and pricing; and high-level operational processes. 


\section{Table 1. Recommendations}

\begin{tabular}{|c|c|}
\hline Recommended Action & Timing $^{1}$ \\
\hline \multicolumn{2}{|l|}{ Monetary Operations \& Collateral } \\
\hline $\begin{array}{l}\text { Collateral adequacy-NBG should undertake a regular forecast of expected liquidity } \\
\text { changes going forward and map these against the NBG's collateral expectations for the } \\
\text { system. }\end{array}$ & Short-term \\
\hline $\begin{array}{l}\text { Collateral strains if identified - should a collateral shortfall be identified necessitating an } \\
\text { NBG response, the NBG should identify ex-ante what collateral could be accepted. }\end{array}$ & Short-term \\
\hline $\begin{array}{l}\text { Under its normal framework, this could involve expanding some of the criteria for existing } \\
\text { high quality credit claims (such as debtor concentrations in line with the NBG's risk } \\
\text { tolerance), or in the case of a systemic need for liquidity, the NBG could temporarily } \\
\text { accept FX collateral (with haircut 'add-ons'). }\end{array}$ & \\
\hline $\begin{array}{l}\text { Different types of systemic responses - the nature of the NBG systemic response will be } \\
\text { guided by the particular type of stress that has impacted the market. The NBG should } \\
\text { document the triggers necessitating each particular type of response. }\end{array}$ & Short-term \\
\hline $\begin{array}{l}\text { The proposed systemic response operation presented by the NBG looks to be in order- } \\
\text { though the NBG should immediately resolve issues around the use of collateral that } \\
\text { matures within an operation as this could constrain the collateral holdings of the system. }\end{array}$ & Short-term \\
\hline $\begin{array}{l}\text { However, the proposal for a committed liquidity facility does not appear to be well } \\
\text { grounded-in normal times, there does not appear to be a dearth of high quality collateral. } \\
\text { Instead any systemic need should be catered for through the measures discussed in this } \\
\text { note. }\end{array}$ & \\
\hline $\begin{array}{l}\text { NBG credit claim verification - continue with the proposed move of the credit claims } \\
\text { existence and verification process to the operational area of the NBG. }\end{array}$ & Short-term \\
\hline $\begin{array}{l}\text { Collateral valuation - market values should be estimated and applied to treasury bills and } \\
\text { bonds accepted as NBG collateral, to protect the NBG balance sheet and to help banks } \\
\text { better price risk out the curve. The same valuation methodology should hold for other } \\
\text { securities accepted by the NBG. }\end{array}$ & Short-term \\
\hline $\begin{array}{l}\text { Credit claim risk controls - consider the introduction of limits or pricing 'add-ons' for } \\
\text { credit claims used in monetary policy operations to promote the correct incentives with } \\
\text { regard to the use of this asset class. }\end{array}$ & Short-term \\
\hline $\begin{array}{l}\text { Global Master Repurchase Agreement (GMRA)-The NBG move to an internationally } \\
\text { recognized GMRA planned next year is a positive development, and will help foreign } \\
\text { bank' participation in the interbank market. }\end{array}$ & Short-term \\
\hline $\begin{array}{l}\text { Removing any ownership restrictions in NBG certificates of deposit }(C D s) \text { - the NBG } \\
\text { should ensure that there are no restrictions regarding the types of entities that can own its } \\
\text { CDs. }\end{array}$ & Short-term \\
\hline
\end{tabular}




\begin{tabular}{|c|c|}
\hline Table 2. Recommendations & (concluded) \\
\hline Recommended Action & Timing \\
\hline $\begin{array}{l}\text { Formalizing Georgian treasury forecasts-initiate formal engagement with the Treasury } \\
\text { in order to improve the quality of the Treasury's forecasts. In this regard, it may be } \\
\text { useful to establish a Memorandum of Understanding }(\mathrm{MoU}) \text {. }\end{array}$ & Short-term \\
\hline $\begin{array}{l}\text { Publication of autonomous factors and forecasts - give consideration to publishing, on a } \\
\text { daily basis, the net autonomous factors for the system—and at a later stage NBG } \\
\text { forecasts - which will help the market determine the liquidity position of the system. }\end{array}$ & Short-term \\
\hline \multicolumn{2}{|l|}{ Liquidity Coverage Ratio } \\
\hline $\begin{array}{l}\text { Liquidity Coverage Ratio (LCR) run-off ratios-consideration could be given to } \\
\text { assessing the appropriateness the currently proposed FX run-off ratios used in the } \\
\text { proposed LCR framework given the limited ability of the NBG to meet FX liquidity } \\
\text { needs of individual banks or of the system. }\end{array}$ & Short-term \\
\hline \multicolumn{2}{|l|}{ Market Deepening } \\
\hline $\begin{array}{l}\text { Market deepening - an active primary government bond market is a pre-condition for } \\
\text { building and enhancing secondary market activity and liquidity, as currently the risk free } \\
\text { curve is not well defined beyond the very short-end, which increases financial stability } \\
\text { risks. }\end{array}$ & Medium-term \\
\hline $\begin{array}{l}\text { Collateral framework contributing to market development - the NBG's collateral } \\
\text { framework can provide a means for promoting standards for quality, transparency, } \\
\text { standardization and simplicity to help develop term funding markets, which could } \\
\text { provide the groundwork for future issuance of securitizations and contributing to overall } \\
\text { financial deepening. }\end{array}$ & Medium-term \\
\hline $\begin{array}{l}\text { Market interaction and further transparency-continue regular engagement with market } \\
\text { participants - both individually and collectively —on issues of market development, } \\
\text { develop a monetary operations manual explaining the NBG's normal and key elements } \\
\text { of its emergency frameworks. }\end{array}$ & Medium-term \\
\hline \multicolumn{2}{|l|}{ Lender-of-Last-Resort } \\
\hline Remove the ability to provide unsecured lending under the NBG law. & Medium-term \\
\hline $\begin{array}{l}\text { Consider publishing a public guideline explaining some of the key elements of the NBG } \\
\text { LOLR framework - including elements such as full collateralization, solvency, viability, } \\
\text { currency, and supervisory intrusion and conditionality—in order to condition market } \\
\text { behavior. }\end{array}$ & Short-term \\
\hline $\begin{array}{l}\text { Provide for the ability—either through the NBG law or through a public guideline- for } \\
\text { the NBG to request a government guarantee when necessary to support the provision of } \\
\text { LOLR. }\end{array}$ & Short-term \\
\hline $\begin{array}{l}\text { Clearly defining the framework internally, including the roles and responsibilities of } \\
\text { other stakeholders. Elements include; internal governance, liquidity monitoring, } \\
\text { collateral and counterparty policy, risk control measures and pricing, and high level } \\
\text { operational processes. }\end{array}$ & Short-term \\
\hline
\end{tabular}




\section{More Detailed AsSessment}

\section{A. National Bank of Georgia's Monetary Policy Framework}

\section{Current status}

\section{The main objective of the monetary policy of the NBG is to maintain price} stability. In order to do this, the NBG uses short-term interbank interest rates (up to seven days) as an operational target. ${ }^{1}$ The main monetary policy instrument of the NBG is its oneweek refinancing auctions, but the NBG also uses three and six-month certificates of deposit auctions. The NBG also has in place a reserve averaging minimum reserve framework and has a standing credit and deposit facility.

\section{In 2015, the reserve money position of the system changed from being one of} liquidity surplus to one of deficit. This shift largely reflected the NBG's FX interventions and increased demand for banknotes. The NBG's FX interventions are now limited to containing excessive volatility that threatens market functioning, though as opportunities allow, the NBG takes conducts transactions in order to build its international reserves. Going forward, the NBG expects that the liquidity deficit will most likely increase (mainly driven by cash in circulation).

3. In 2010, the NBG tried to provide comfort to market participants about its lari liquidity provision. The NBG extended full allotment to seven-day liquidity facilities at fixed spreads above its policy rates. In 2015, the NBG temporarily introduced internal limits on its seven-day auctions in an effort to have some level of control on liquidity volumes in the system. However, these actions resulted in elevated interbank rates and the NBG does not envisage using liquidity limits or guaranteed facilities again. ${ }^{2}$

\section{The NBG recently incorporated certain loans to small and medium-sized} enterprises and residential loans into its collateral framework. The operational checks for these loans are conducted in the supervisory area of the NBG. The NBG also recently introduced corporate bonds into its eligible collateral pool. ${ }^{3}$

5. In terms of other operational aspects - the Georgian Treasury's deposit is placed with the NBG and is not remunerated. There is currently no formal arrangement in place

\footnotetext{
${ }^{1}$ See https://www.nbg.gov.ge/uploads/tibr/tibreng.xlas for interbank rates and volumes, and https://www.nbg.gov.ge/uploads/tibr/mmieng.xls?1476710810483 for an overview of money market indicators.

${ }^{2}$ The NBG liquidity provided in excess of the system wide cap was priced at a penal rate, a cost which in turn, fed into the cost of liquidity in the market. In general, it is not recommended that central banks introduce limits as part of their regular monetary policy operations.

${ }^{3}$ In addition to the assets described, the NBG also accepts lari-denominated NBG certificates of deposit, government securities, and international financial institution bonds.
} 
with the Georgian Treasury with regard to the provision of Georgian Treasury liquidity forecasts. In terms of the NBG's minimum reserve framework, the reserve ratios are in lari ( 7 percent requirement) and FX ( 20 percent requirement). FX requirements are met in FX, with EUR requirements remunerated at the ECB deposit rate (currently negative), and USD currently at zero percent (but linked to FED policy rate $(-50 \mathrm{bps})$ ). The NBG has in place a formal schedule regarding the re-profiling of legacy non-marketable government bonds on its balance sheet, which will be replaced with tradable government bonds with market interest rates.

\section{Assessment and Recommendations}

\section{Monetary policy framework}

\section{The NBG appeared somewhat concerned about the market perception of its} operational framework, which most likely stems a number of depreciation episodes in the past. ${ }^{4}$ In particular, the NBG feels that the market may be concerned that in a stressed environment the NBG may not stand ready to meet a systemic need for liquidity, which could be as a result of actions - or more specifically inactions - taken by the NBG during previous crises (but at a time when the NBG had not fully adopted inflation targeting). However, from discussions with market participants it appears that the market is satisfied the way the NBG's operational framework operates. ${ }^{5}$ When asked what are the NBG's objectives behind its liquidity management, the selected banks stated that the NBG puts sufficient weight on price stability (rather than the FX rate), and that they take comfort from the predictability of the NBG's current liquidity provision and sterilization operations. ${ }^{6}$

7. However, if further NBG comfort is needed-either now or in the future-the NBG could meet structural liquidity needs through a slightly longer-term standard operation, priced at market rates. Structural liquidity is best provided using longer term auctions, and as a means of instilling further confidence in its liquidity management operations, the NBG could consider having in is framework the ability to meet structural liquidity needs - such as resulting from previous FX interventions - and so as to minimize the degree of rollovers in the NBG liquidity providing operations. In such an operation, the

\footnotetext{
${ }^{4}$ For example, in late 2013 , the NBG sold about 15 percent of its reserves, while also allowing the currency to depreciate by 7 percent.

${ }^{5}$ Though at times the interbank rate does settle below the NBG deposit facility rate, which should be investigated further by the NBG (it appears that one small bank may not be so sophisticated from a liquidity management perspective).

${ }^{6}$ As noted in the December 2014 FSAP, the NBG accepted for a period floating rate mortgages as collateral. In discussions with market participants, the withdrawal of these measures was not raised as a concern, but this is not to say that concerns may have existed at the time of the collateral policy tightening.
} 
NBG would set and announce a volume (maybe a certain percentage of the liquidity needs of the system) and the NBG would then be a market rate taker than a rate setter in that particular part of the curve. ${ }^{7}$ A useful tenor to start with could be an operation of one month. ${ }^{8}$

\section{The NBG also raised the question of whether its collateral framework needed to} be expanded further in normal times. At present there does not appear to be a compelling case to expand the collateral accepted under the NBG's standard monetary policy framework. ${ }^{9}$ However, it could be helpful for the NBG to undertake a forecast of expected liquidity changes in the system going forward and compare the results against the expected collateral availability in the system. Such an assessment should be performed on a regular basis, with the goal for the NBG to try and anticipate any expected collateral shortfalls which could require NBG policy actions.

\section{Through this analysis, the NBG should be able to determine if there is a} compelling need to expand its collateral framework. If so, the NBG should examine what other types of assets it is prepared to accept, such as additional higher quality credit claims, including the possible loosening of current concentration limits so that larger high quality credit claims could be accepted..$^{10,11}$

10. The NBG should continue with the proposed move of the credit claims existence and verification process to the operational area of the NBG. It is common for central bank collateral checks to be performed in the operational area of the central bank (e.g., the European Central Bank (ECB) and the Bank of England (BoE)) rather than the supervisory

\footnotetext{
${ }^{7}$ The ECB has a maintenance period operation as part of its toolkit.

${ }^{8}$ This would be helpful if the NBG had a monthly reserve maintenance period, but this also needs to be balanced against the liquidity forecasting capabilities of the banks over a longer (maintenance) period.

${ }^{9}$ On first inspection, it appears that there is sufficient collateral within the system, because as at September 27, 2016, the total monetary policy borrowings stood at GEL 950 million, while unencumbered monetary policy eligible collateral buffers stood at roughly GEL 2,595 million. Though the mission team did not discuss trends in the liquidity deficit (i.e., amount borrowed by the system) or projections for the liquidity deficit going forward.

${ }^{10}$ The NBG currently imposes a credit claim limit of 1 million lari per debtor.

${ }^{11}$ The NBG could examine the acceptance of bank certificates of deposit, but there are two main reasons why the majority of central banks stay shy of this type of collateral; (i) the potential for reciprocal use of collateral needs detailed monitoring (this practice was evident amongst the Icelandic banks in the Eurosystem, and (ii) 'close links' would need to be monitored so that a bank does not subject collateral of which it has a significant relationship (for example, an entity within its own banking group). See https://www.ecb.europa.eu/press/pr/date/2015/html/pr150220.en.html for further details on how the ECB tries to control for 'close links.' However, the acceptance of these assets could contribute to the development of term-funding markets, but it may be preferable to develop secured rather than unsecured markets.
} 
area, mainly because the supervisory area has prudential — rather than central bank lending and related collateral management—responsibilities.

\section{Systemic response}

11. The type of NBG response needed during a period of market strain will be largely determined by the particular type of market strain evident. For example, the acceptance of assets outside of its normal framework would address different demands (the need for additional lari liquidity) than would the lengthening of the maturity of its operations (should the demand for term liquidity be putting undue pressure on short-term rates).

12. While a systemic response is often associated with an increase in local currency reserves, this is not necessarily the case. Moreover, depending on the nature of the response, it could include some element of sterilization. Importantly though, if longer term liquidity providing operations are being offered, they should be priced at, or even at a small margin to, market rates, to be consistent with the NBG's monetary policy objectives, and also to make any exit from these non-standard arrangements easier.

13. Nonetheless, the mission discussed the NBG's proposed longer-term operation, which could be issued in response to market strains. The structure, which builds on MCM advice, looks very promising. Specifically, should there be a need for additional term lari liquidity, the NBG would launch at its initiative a longer-term operation (with an envisaged maturity of roughly 6-12 months, but which can be modified according to the needs of the market). The operation would be priced at market rates and the NBG will accept a wider collateral base, if needed. While such an operation is not necessary at this juncture, it is nonetheless preferable that the begin preparing how it could accept additional collateral (such as FX collateral) and what type of additional credit claims could be accepted (either existing high quality claims subject to lower debtor concentration limits, or less preferably lower quality credit claims not currently accepted under its regular framework but subject to stringent risk controls). ${ }^{12}$

- $\quad$ The NBG should try to prepare as much as it can in advance the risk controls that could apply to such assets - including valuation techniques and haircuts - so as to avoid rushed decisions at the time of need. When formulating its haircuts, the NBG should consider the use of a haircut 'add-on'-over and above the base haircut applied to the security — in order to better protect the NBG should there be adverse

\footnotetext{
${ }^{12}$ Though it seems to be the case that, at present, a counterparty cannot pledge collateral that matures within the term of the operation, if so, this would need to be addressed first.
} 
movements in the FX rate and also to discourage further dollarization through the acceptance of these assets. ${ }^{13}$

- In performing this work, the definitions of High Quality Liquid Assets (HQLA) in the LCR framework also could be assessed. While the LCR is predicated on an assumption that HQLA be liquefied in the private markets in the first instance, in a stress situation there might be need for the central bank to provide liquidity against a bank's HQLA which may or may not align with the NBG's collateral requirements (including haircuts).

\section{Should the availability of collateral not be considered sufficient, then the NBG} could consider the acceptance of credit claims (bank loans). In such circumstances, the NBG should try to identify as soon as possible the types of credit claims that it is prepared to accept in line with its risk tolerance, and formulate eligibility criteria including risk controls. ${ }^{14}$

\section{Even at this early stage counterparties could be asked to pre-position the collateral with the NBG so that it can conduct its checks and the counterparty to undertake any required due diligence. The pre-positioning process is essentially a due diligence process undertaken by the NBG to confirm that the loans are in line with its eligibility criteria. Legal title to the collateral is not transferred to the Bank at the pre- positioning stage, instead this process is purely an eligibility and validity check. ${ }^{15}$ The NBG could hire legal counsel to do the inspection of documentation in the case of credit claims, and also other agencies in terms of credit assessment. ${ }^{16}$}

\section{It is recommended that the NBG ensure that its current monetary policy framework is flexible to cater for possible future liquidity shocks, but without disclosing the exact structure of the response so that the system's ability to self-insure is not undermined. In this regard, it may be useful for the NBG to publish a monetary operations}

\footnotetext{
${ }^{13}$ Bank for International Settlements (BIS) "Central bank collateral frameworks and practices" (2013) available at http://www.bis.org/publ/mktc06.pdf, provides a good overview of country practices regarding the levels of these 'add-ons.'

${ }^{14}$ In the case of credit claims for monetary policy purposes this would normally involve the establishment of eligibility criteria and risk controls for performing loans only. It would be expected that for emergency idiosyncratic operations, credit claims with some level of impairment may need to be looked at, and suitably controlled from a risk perspective, if it was decided to accept these assets.

${ }^{15}$ Nonetheless, it would be helpful if the counterparty updated the information (certain variables for loan collateral, such as repayment amounts, etc.) relating to pre-positioned portfolios on a monthly basis.

${ }^{16}$ Confidentiality agreements with these entities could be helpful.
} 
document that explains its framework in normal times, and discloses certain elements of its framework in emergency times (both during systemic and idiosyncratic cases). ${ }^{17}$

\section{Other measures}

\section{The NBG discussed the possibility of introducing FX swaps as part of its}

standard framework. These could be a useful mechanism to stabilize any FX swap market tension that could influence the dynamics of other short-term rates and distort the monetary policy implementation. These could be introduced as a standing facility and priced accordingly, with limits to lend support to the local currency. However, some of this work goes beyond the mandate of this current mission and further MCM engagement could be useful before this and other possible arrangements - such as interest rate swaps currently being considered by the NBG-are established. ${ }^{18}$

\section{Market values should be estimated for Georgian Treasury bills and bonds and} applied to collateral taken by the NBG. In the absence of continuous market pricing, information from the most recent primary auction, market contacts, and pricing from NBG sterilization operations should be used to arrive at the best guess of the market value of each government security. Ideally, securities would be revalued daily to ensure that collateral values were sufficient to cover the amount of loans. Also if there was a shortfall (beyond a pre-specified level), the NBG would be entitled to make a margin call (i.e., a request more collateral). The NBG should consider incorporating these commonly used features to reduce risks, bearing in mind the increased operational requirements of doing so. ${ }^{19}$

\section{The NBG could formally engage with the Georgian Treasury so that it can collect and produce the best possible projections on government expenditure and} revenue. ${ }^{20}$ To assist with this work, it may be necessary for an $\mathrm{MoU}$ to be established between the Georgian Treasury and the NBG to regulate the information exchange related to liquidity forecasting. An MoU would typically obligate the Georgian Treasury to provide, at

\footnotetext{
${ }^{17}$ See for example, the ECB's General Documentation available at https:/www.ecb.europa.eu/press/pr/date/2015/html/pr150831_1.en.html or the BoE's Red Book available at http://www.bankofengland.co.uk/markets/Documents/money/publications/redbook.pdf.

${ }^{18}$ FX swaps could also be a positive development from a market development perspective, but their objectives would need to be clear. For example, if used as a monetary policy fine tuning instrument, the maturity of these operations should be consistent with the current money policy instruments. On the other hand, if used as a market development instrument, FX swaps should be two-way and be launched regularly.

${ }^{19}$ Furthermore, the NBG should remove any restrictions around the acceptance of collateral with a maturity date less than that of the operation, as this could constrain collateral holdings of the system.

20 The TA mission did not look at the liquidity forecasting methods of the NBG or the methods used to determine the amount of liquidity it injects into/takes from the system.
} 
a minimum, weekly information to the NBG in support of its monetary policy role. Such an MoU could also generate an internal Georgian Treasury initiative to strengthen forward planning by a separate cash management unit, usually located in the Georgian Treasury. Cash flow forecasts should, as a start, be weekly and looking two to three months ahead; be regularly updated and rolled forward. ${ }^{21}$ These forecasts should be independent of the budget execution process and be based on information received from ministries, departments and agency which are the largest spenders, and from the Revenue Authority. These forecasts should be cross-checked against actual flows and the reasons for errors discussed with the Georgian Treasury.

\section{Imposing limitations on ownership of NBG certificates of deposit (CDs) may not} be the most appropriate means of preventing direct competition with government securities. NBG sterilization should concentrate at the very end of the yield curve, via offerings of fixed volume variable rate tenders, creating space for the MoF to issue further out the curve. However, a difficultly arises as the MoF appears to be considering using some of the space that should be reserved for the NBG, for its own cash management purposes. ${ }^{22}$ In order to create additional high quality assets for the system, NBG issuances should be issued without restriction and if their issuance creates tensions between the NBG and the MoF (and also as a means of not segmenting the short-end of the curve) overtime, it may be useful for the NBG to work with the MOF to allow for the use of government securities in sterilization operations. Funds raised through these instruments would need to be left with the NBG in a blocked account and remunerated appropriately (for example, at a rate equivalent to that the securities or issued to the market).

\section{MARKETS}

\section{A. Current Status}

21. Currently, there are 21 banks operating in Georgia. This number comprises local and foreign owned entities. Overall, banks appear to be well capitalized and liquid (see recent Article IV). In terms of structure, the sector is highly concentrated, with the two largest banks accounting for 58 percent of assets, though there does not seem to be an issue of

\footnotetext{
${ }^{21}$ Even though domestic and foreign currency assets are close substitutes in a highly dollarized economy such as Georgia, central bank operations may affect both markets differently. An effective liquidity monitoring of these markets requires clearly identify the sources of potential liquidity pressures both in FX and lari money markets.

${ }^{22}$ The longest tenor the NBG can issue CD's is six months, while the shortest tenor the MoF can issue bills is one year, though the option of issuing six-month bills is being explored, and possibly shorter tenors for cash management purposes.
} 
segmentation in the money markets, something that you would normally expect to see with when only a few banks dominate the banking system.

\section{The lari money market constitutes an important source of liquidity for the} financial sector, with the main activity taking place in the unsecured market, and to a lesser extent the FX swap and the developing secured market. ${ }^{23}$ According to the NBG, roughly five or six banks are active in the interbank market. The NBG imposes limits on banks' net open positions The NBG is working with market participants so that it can move to an international Global Master Repurchase Agreement (GMRA) possibly next year.

Dollarization is significant in Georgia, with credit and deposit dollarization levels standing at roughly 60 percent. However, from discussions with selected banks, it appears that at least these banks do not have significant net open positions. ${ }^{24}$

\section{The government funds itself mainly through cheaper international borrowing} (international financial institution (IFIs)). This has two main implications for the system: (i) this requires active (and potentially costly) sterilization by the NBG; and (ii) there are no benchmark lari government securities in the local market. Currently, there are limited options for term funding in lari, and even where term lari deposits do exist, they can be converted into FX. In discussions, market participants expressed concerns about the ability to price risk out the curve.

\section{B. Assessment and Recommendations}

\section{Georgian funding markets appear short-term in focus, with legacy concerns} about inflation/depreciation possibly being a driver in this regard. Combined with the fact that the government finances itself mainly through IFIs, there are limited money market instruments in Georgia which increases the vulnerability of banks in Georgia to liquidity shocks.

25. The basic elements for well-functioning money markets are in place, but a number of factors are hindering the evolution of deeper markets. These factors mainly relate to the lack of reliable and market relevant financial benchmarks, and a narrow range and insufficient supply of money market instruments. It appears that there are ownership restrictions regarding the types of entities that can own its sterilization instruments - only regulated banks — and removing such clauses could help with market deepening.

26. Policies focused on enhancing trading and price discovery out the curve are therefore needed. Adding to the supply of government products beyond the two-year space

\footnotetext{
${ }^{23}$ The market cited that the FX swap market was particularly thin, possibly reflecting the current macroeconomic environment.

${ }^{24}$ The NBG does impose limits on banks' net open positions. http://www.nbg.ge/uploads/legalacts/supervision/nbg1.4.5.1regulation_settingeng.pdf.
} 
will better support the development of the "risk free" benchmark yield curve, which is an essential requirement for financial deepening. In its absence, the market is very much shortterm in focus which increases the vulnerability of the banking system to liquidity shocks going forward.

\section{Building the yield curve is usually an outcome of regular issuances of} government bonds as shown by the international experience. The NBG has plans to term down its six-month sterilization instruments to allow the Georgian Treasury to take this space on the curve. This is a positive move as its supports the transmission of monetary policy, allows for a better separation of strategic debt management decisions from short-term liquidity management considerations, and reinforces the Georgian Treasury's role in developing the securities markets. More generally, the introduction of local currencydenominated securities with credible indexation systems, the development of markets for instruments to hedge currency risks and capital markets are all measures that can help discourage dollarization.

28. It could be beneficial for the NBG to look to develop the securitization market, but this is more of a longer-term goal. Nonetheless, the growth of the securitization market depends heavily on the overall efficiency of broader capital markets. The liquidity and accuracy of the yield curve in the relevant maturities, the availability of efficient hedging instruments (derivatives or short sales), and the ability to obtain inexpensive short-term financing through repurchase markets are all important preconditions to an active and robust market.

\section{NATIONAL Bank OF GeORgIA's LiQuidity Monitoring}

\section{A. Current Status}

29. The NBG has in place a liquidity metric where essentially an average of month's liquid assets shall be no less than $\mathbf{3 0}$ percent of average of month's liabilities. The NBG is planning to implement a LCR that will be stricter than the current ratio. ${ }^{25}$ The main differences between this proposed LCR and that proposed by Basel are as follows; less liquid assets (e.g., company stocks) that can't be immediately converted into cash are excluded from high quality asset definitions, while the NBG LCR includes a liquidity requirement by currency and adopts higher outflow rates as levels of deposit concentration increase and based on client residence and account type. The NBG also noted their intention to introduce a ratio on net stable funding requirements in the medium-term.

${ }^{25}$ The proposed LCR ratio will be applied to all banks. 


\section{B. Assessment and Recommendations}

\section{The NBG has discussed internally whether a committed liquidity facility should be implemented to meet shortfalls of high-quality liquid assets in stressed situations} when the proposed LCR is introduced. However, the introduction of a committed liquidity facility (CLF), ${ }^{26}$ does not appear to be the most appropriate tool in response to a systemic shock. Such arrangements are intended to cater for instances where there is a shortage of high quality liquid assets during normal times, and banks pay a commitment fee that allows the possibility for them to access central bank repos using less liquid collateral. ${ }^{27}$ However, there does not currently appear to be a shortage of HQLA within the Georgian system, and such an arrangement if introduced could be more akin to emergency liquidity assistance (but with a commitment rather than being at the NBG's discretion, and also without safeguards such as possible conditionality), making its objectives less clear.

\section{To avoid having the NBG essentially backstop the market, it may be better to review the current run-off rates of the proposed LCR arrangement. ${ }^{28}$ Currently, FX} deposits receive a lower run-off rate (e.g., 18.5 percent) compared with similar lari deposits (e.g., 21.5 percent), despite the fact that the NBG has limited capability to meet FX liquidity needs of the system (as compared to the unlimited capacity to provide lari) should individual banks or the system experience FX outflows beyond existing buffers. ${ }^{29,30}$ Further, MCM

\footnotetext{
${ }^{26} \mathrm{~A} \mathrm{CLF}$ is a contractual arrangement between a bank and the central bank, through which banks - for a feehave on-demand access to liquidity. This Facility counts toward high quality liquid assets in LCR ratios.

${ }^{27}$ Any access to the CLF should be seen as a last resort and only once all other reasonable steps have been taken to manage their liquidity risks without recourse to the NBG, while a commitment fee should try to equalize incentives between those who have access and those who do not.

${ }^{28}$ Consideration should be given to reassessing the appropriateness of FX run-off assumptions. In particular, the preferential treatment of FX compared with local currency within the LCR framework. Within the LCR framework, FX deposits should be treated as 'less stable,' which attracts a higher run-off rate (see paragraph 79 of Basel III: The LCR and liquidity risk monitoring tools, January 2013). Equally within the LCR there is also an expectation that the currencies of the stock of HQLA should be similar in composition to the operational needs of the bank. Banks and supervisors cannot assume that currencies will remain transferable and convertible in a stress period, even for currencies that in normal times are freely transferable and highly convertible. Also, if the NBG is pursuing a de-dollarizing strategy, preferential treatment for FX is questionable.

${ }^{29}$ As noted in the 2014 FSAP, the growth of FX deposits warrants close monitoring and 'the NBG should consider applying further measures to prevent the build-up of systemic liquidity risk.' (Box 1, Macroprudential Technical Note available at https://www.imf.org/external/pubs/cat/longres.aspx?sk=42588.0). Such a consideration could involve increasing run-off rates for FX deposits.

${ }^{30}$ A central bank's ability to provide LOLR in FX will in most cases be limited, and this should be made clear to the market but without announcing limits. Prudential tools should be used to reduce the risk that such needs arise, and would outstrip FX resources available but may not be sufficient to eliminate it.
} 
assistance could be helpful in this regard, and also in relation to assessing that liquidity risks are being accuracy measured and that term funding is being encouraged.

\section{LENDER-OF-LAST-RESORT}

\section{A. Current Status}

\section{The NBG's ability to provide LOLR is set out in Article 33 of the NBG law.} According to the law, the NBG can extend loans no longer than three months, with an interest rate not be less than the NBG standing facility rate, and against collateral as decided by the NBG Board. Article 33 also states that “in emergencies, where country's financial system may be threatened, the decision of the Board of the National Bank may permit issuance of loan for longer term, with different interest rate and without security."

\section{B. Assessment and Recommendations}

33. The NBG should cease having the ability to provide unsecured lending; this should be supported through the revision of NBG law. The purpose of securing collateral is to minimize the potential credit risk to the central bank balance sheet that may occur in case of default. The requirement for collateral also provides a natural limit to lending provided, as an institution cannot borrow more than its available unencumbered assets accepted by the central bank. Until the NBG Act is amended, the exclusion of unsecured lending should be ratified by the NBG Board and reflected in the published Guidelines.

34. In the absence of adequate collateral, the NBG should make explicit the ability to request a government guarantee so that LOLR could be extended. Risks associated with LOLR can be extremely large, given the illiquidity of the collateral (as high-quality collateral has been exhausted) and the distressed nature of the counterparty (there could potentially be underlying issues of insolvency). One of the key tasks of a central bank is to protect its own balance sheet. ${ }^{31,32}$

35. The NBG should also consider publishing a public guideline explaining some of the key elements of the NBG LOLR framework in order to condition market behavior. These elements should include at a minimum, requirements for solvency and viability, and

\footnotetext{
${ }^{31}$ In general, risks associated with monetary policy are generally not indemnified; to preserve the independence of the central bank the ensuing risks are covered by its capital. Risks associated with LOLR are typically covered by government guarantees.

${ }^{32}$ Indemnities should be fully enforceable, irrevocable and unconditional guarantees that rank pari passu with other government obligations.
} 
supervisory intrusion and conditionality. This guideline could also allow for the NBG to request a government guarantee when necessary. ${ }^{33}$

36. In order to anticipate the need for LOLR liquidity, the NBG should monitor lari and FX needs from an operational perspective. In general, a central bank should not be taken by surprise by an institution's need for LOLR, and should actively monitor recent liquidity developments across individual counterparties and carry out liquidity projections under different specified stress assumptions. As part of future work in this area, MCM can work with the NBG with regard to developing a template to help perform this liquidity monitoring.

\footnotetext{
${ }^{33}$ For more details on LOLR please see Marc Dobler, Simon Gray, Diarmuid Murphy, and Bozena RadzewiczBak, 'The Lender-of-Last-Resort Function after the Global Financial Crisis,' IMF Working Paper (WP/16/10), January 2016: https://www.imf.org/external/pubs/ft/wp/2016/wp1610.pdf.
} 